\title{
CHARME LABILE
}

Par cet après-midi de juillet - 1 'heure avancée Ecoute! Tu entends les cicades bourdonnantes: quel cri Strident qui évoque les chansons entrelacées De bois et d'oiseaux accouplés en plein midi, Chaud, nonobstant joyeux. Ardent. Mais paresseux non! Electrique plutôt sous ce soleil si beau si vaste Sous ce ciel si bleu à nuages (calme phénomène blond) Qui flottent sereins au-devant d'un médianoche néfaste, Moi proie à c'tte heure des vautours atroces. Nul mouvement

Alors - car toutes les futures forces seront perdues Et tout sera veuf, tout feutré, au noir firmament. Nécrose. Et les voix de tous les rossignols tués tues.

Jan Palister

Bowling Green State University 